\title{
Microfacies, Sedimentary Environment and Sequence Stratigraphy of Gadvan and Darian Formations in the Zagros Basin, South of Semirom, Iran
}

\author{
Mohammad Kazem Hamedanian', Seyed Hamid Vaziri2*, Mahnaz Amir Shakarami3 , Mehran Arian1, \\ Naser Arzani3 \\ ${ }^{1}$ Department of Geology, Science and Research Branch, Islamic Azad University, Tehran, Iran \\ ${ }^{2}$ Department of Geology, North Tehran Branch, Islamic Azad University, Tehran, Iran \\ ${ }^{3}$ Department of Geology, Payam Noor University, Isfahan, Iran \\ Email: *h_vaziri@iau-tnb.ac.ir
}

How to cite this paper: Hamedanian, M.K., Vaziri, S.H., Shakarami, M.A., Arian, M. and Arzani, N. (2016) Microfacies, Sedimentary Environment and Sequence Stratigraphy of Gadvan and Darian Formations in the Zagros Basin, South of Semirom. Open Journal of Geology, 6, 1169-1186.

http://dx.doi.org/10.4236/ojg.2016.69086

Received: August 6, 2016

Accepted: September 24, 2016

Published: September 27, 2016

Copyright $\odot 2016$ by authors and Scientific Research Publishing Inc. This work is licensed under the Creative Commons Attribution International License (CC BY 4.0).

http://creativecommons.org/licenses/by/4.0/

\begin{abstract}
Gadvan and Darian formations are in the upper part of Khami group that has been deposited in the highland Zagros zone and the southern Margin of Neotethys. These formations outcrop in the south of Semirom (Agh-Dagh Mountain) consist of Orbitolina limestones and marly limestones with a Late Barremian-Aptian age and thickness of 520 meters. Based on field characteristics, petrographic and texture of facies, these rocks consist of Oregonian facies (Urgonian facies) with 12 carbonate microfacies which are deposited in Lagoon, barrier and shallow open marine. The absence of loss and flows of turbidities indicates that carbonate platform of Gadvan and Darian formations in the studied area are (Hmoklinal) platform type. Abundance of rudist (bivalves) and peloid markers show that there is a Photozoan collection in tropical climates. In the above sedimentary succession, from a sequence stratigraphic perspective, three sedimentary cycles were recognized which deposited in a platform model. The Gadvan Formation overlies on Fahliyan Formation disconformable and is covered by Darian Formation gradual with reducing the amount of marl and increase of limestone. The Kazhdumi Formation is exposed disconformably with hematite nodules and oxidized sediments over the Darian Formation. On the basis of petrographic studies, diagenetic process of Gadvan and Darian formations in the study area includes cementation, the physical and chemical density and replacement processes such as pyritation, ironies and silica. Porosity observed in the study area is mainly inter-granular porosity type, modular and vaggy.
\end{abstract}




\section{Keywords}

Zagros, Gadvan, Darian, Cretaceous, Sequence Stratigraphy

\section{Introduction}

Lower Cretaceous in the Zagros system includes marine carbonate sediments, which is mostly limestone and marl, and covers most of Zagros basin. Although carbonate and marine sediments of Jurassic are covered disconformable by Cretaceous facies, Zagros sedimentary rocks have not the same facies and same depositional environments [1]. The Gadvan and Darian formations are observed in the upper part of the Khami Group. Gadvan Formation is locally source of oil, and cap rocks for Fahlian oil reservoir and with Darian Formation make the Khami group. Its type section introduced for the first time by James and Wynd [2] at the eastern end of the Gadvan Mountain, 40 $\mathrm{km}$ northeast of Shiraz. The Gadvan Oregonian facies are neritic limestone with fossilized river and orbitolinide as Barremian and Aptian extensive a large part of the Tethys Ocean, the Mediterranean region and Iran to Central Asia. Limestones contain rudist, Orbitolinidae, miliolids, calcareous algae, corals, sponges, bryozoan and gastropods. The limestone facies belong to the warm sea and low depth. These formations in terms of lithostratigraphy, biostratigraphy, microfacies, sedimentary environment, paleontology and sequence stratigraphicby have been studied by others such as Wales [3], Kheradpir [4], Golestane [5], Hussein et al. [6] [7], Habibi, et al. [8], Ghalavand [9], Safari, et al. [10], Barzehgar [11], Amir Shah Karami, et al. [12], Motiei [13], Abyat [14], Sedaghat [15], Afghah, et al. [16].

\section{Study Section}

The study section is located in the south of Semirom (geological map of Semirom on scale 1/100,000) and the south slopes of Agh Dagh Mountain, in the Zagros folded with co-ordinates: N 31 $05^{\prime} 08^{\prime \prime}$; E 51 $55^{\circ} 14^{\prime \prime}$ (Figure 1). The Gadvan Formation (150 m) consists of thin- to medium-bedded marly limestone, marl, fossiliferous limestone and nodular limestone and the Dariyan Formation $(370 \mathrm{~m})$ consists of medium- to thickbedded Orbitolina limestones (Figure 2).

\section{Research Method}

The best stratigraphic section of Gadvan and Darian formations in the study area has been selected and, systematic sampling was done on the basis of lithological and facies changes and in total 130 samples were collected. Microfacies were described and the depositional environment evaluated based on Wilson [17], Dunham [18], Ember and Kalavan [19], Wright [20] and Flugel [21]. To review and approve the dolomites, thin sections were stained by Alizarin Red (rd-S) and potassium ferrocyanide with method of Dickson [22]. 


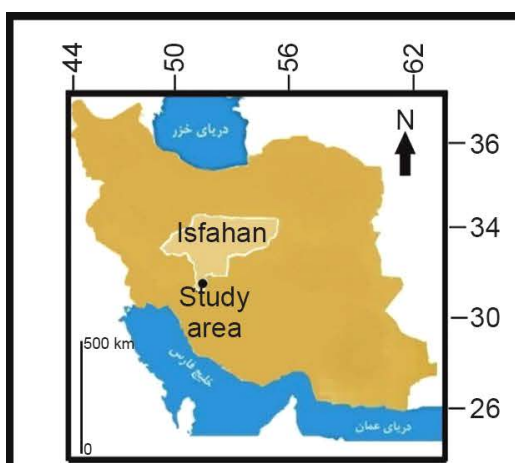

(A)
(B)
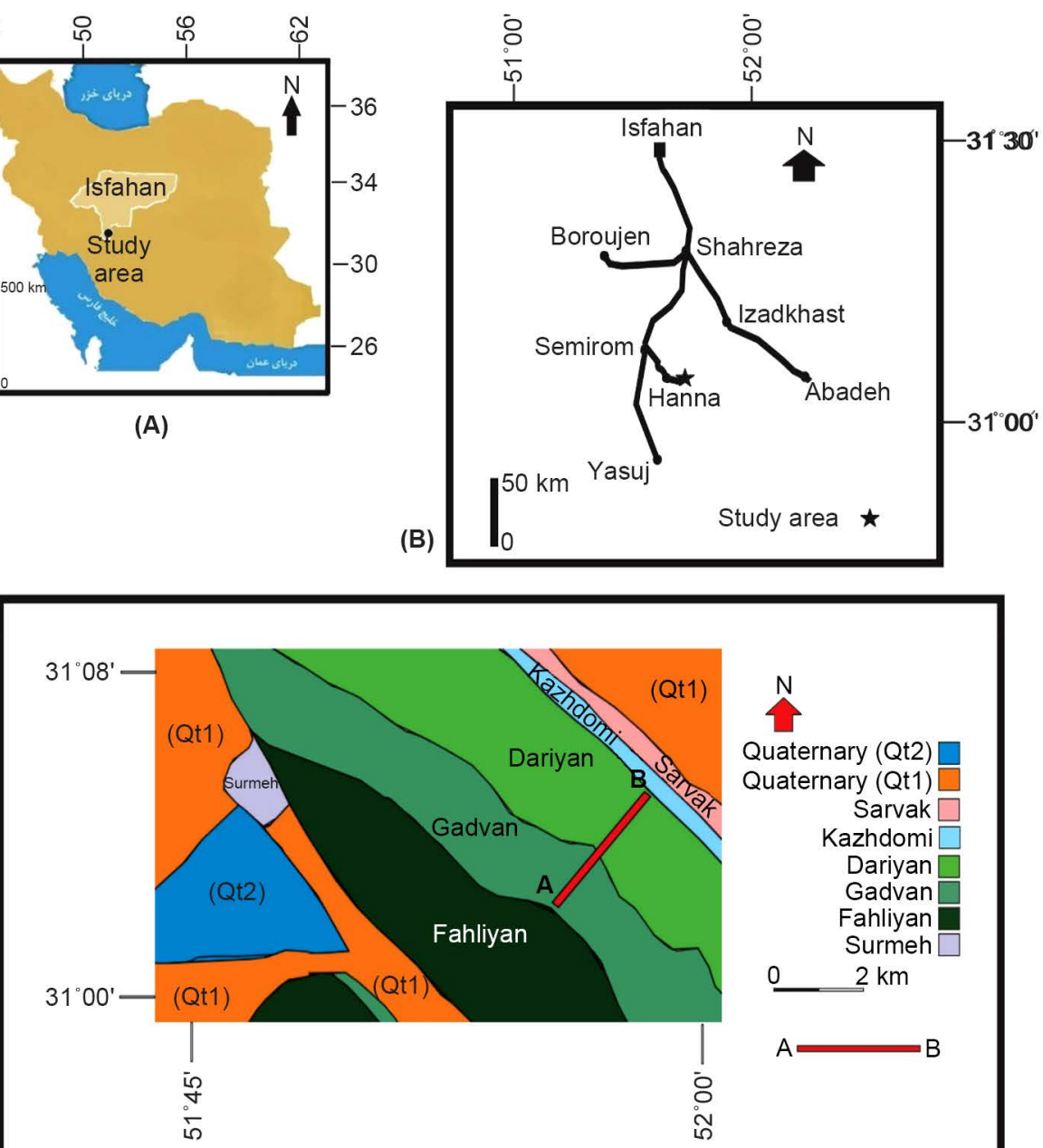

Quaternary (Qt2) Quaternary (Qt1) Sarvak $\square$ Kazhdomi $\square$ Dariyan $\square$ Gadvan Fahliyan Surmeh $\square$ $0 \quad 2 \mathrm{~km}$

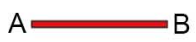

(C)

(D)

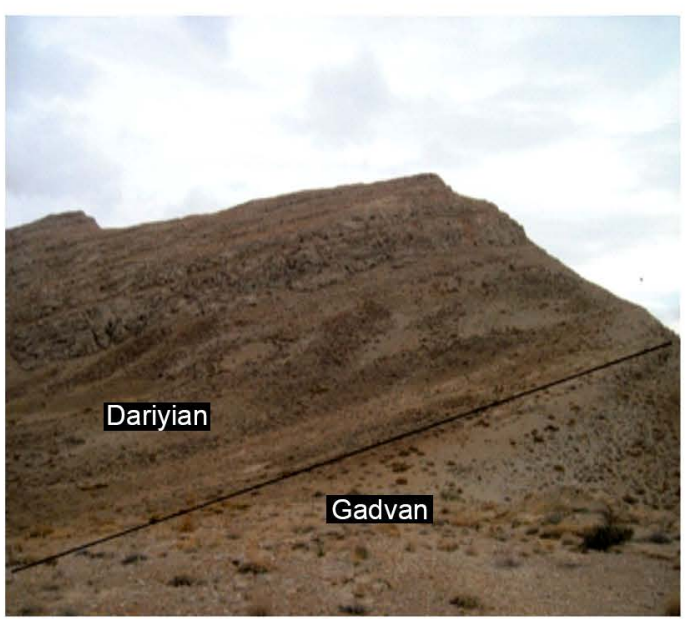

Figure 1. (A) Showing the study area in Iran, (B) Location and access roads to the study area in south of Semirom, Zagros basin, (C) Location of studied section in geological map of Semirom (scale 1/100,000), (D) View of the Agh Dagh Mountain in southern Semirom, photo is looking to north. 

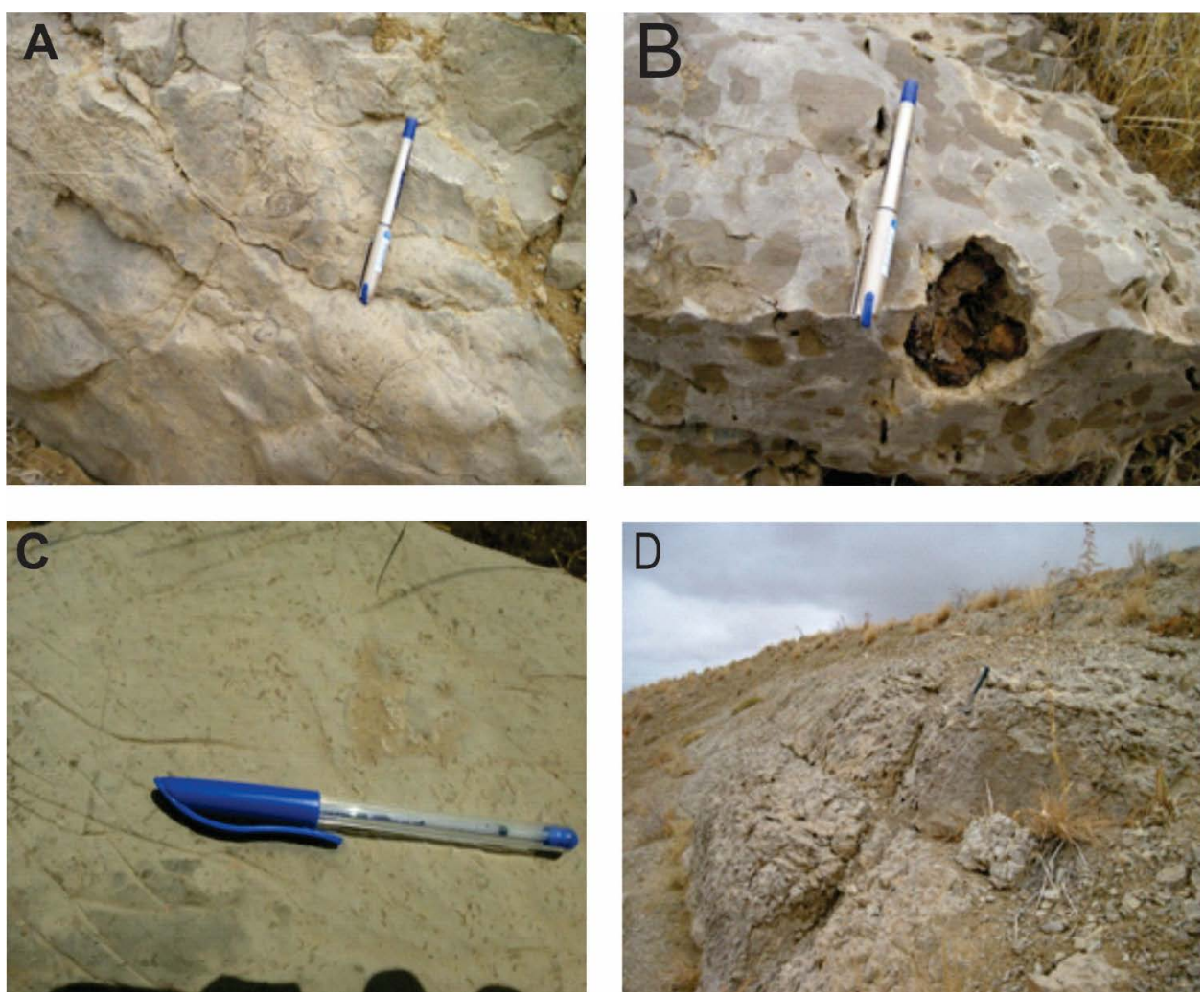

Figure 2. (A) Fossiliferous limestone of Gadvan Formation, (B) nodular limestone of Gadvan Formation, (C) Orbitolina limestone, (D) Thick-bedded limestone of Gadvan Formation.

\subsection{Microfacies of Gadvan and Darian Formations}

Based on microscopic studies and texture features 12 carbonate facies were identified at three depositional environments including the lagoon ( 3 microfacies), barrier ( $5 \mathrm{mi}$ crofacies) and shallow open marine (4 microfacies).

\subsubsection{Open marine Facies}

\section{1) Planktonic Mudstone}

Allochems of this facies are very low, slightly less than $10 \%$ which includes parts of sponge spicule, planktonic foraminifera, bivalves, and gastropods. This facies are composed of micrite including existing structures in this sub-facies iron oxide concentration that are associated with stylolite. These facies were observed in thin sections $54 \&$ 55 and dark gray color is one of the properties of the facies with abundant fractures and low fossils (sample 54). The presence of planktonic foraminifera, bivalves, and sponge spicule show decreasing energy and increasing depth. The facies was deposited in a low energy environment and calm sea [17] [21] [23]-[25].

\section{2) Bioclast Wackestone}

Allochems of this facies are very small and slight that include very small parts of siliceous sponge spicule, planktonic foraminifera, echinoids, bivalve, and gastropods. Pyrite fragments of fossil (the restoration) effect of fossils (trace fossil) for burrow. Texture of facies is composed of microcrystalline (samples 2, 10, 99, 120). The presence of 
planktonic foraminifera, bivalves, sponges and thin-bedded microcrystalline show decreasing energy and increasing depth. The facies were deposited in low energy and a calm sea [17] [23] [24] [26].

\section{3) Bivalvida Wackestone}

Allochems of this facies are very low, negligible including thin of bivalves, Gastropod, radiolarian, sponge spicule and ostracods. This facies are composed of microcrystalline textures. The average gray limestone facies will see in the field by small effects of macrofossils (sample, 6). The presence of planktonic foraminifera, bivalves, and sponge spicule shows decreasing energy and increasing depth. The facies was deposited in a low energy environment and calm sea [17] [23] [24] [26].

\subsubsection{Barrier Facies Belts}

In the facies belts, 5 microfacies were determinate that often include a variety of benthic microfossils, interclast, Oolite, ploid, bioclast and aggregate grains that leading to packstone with grainstone rocks texture. Based on lithological composition and fossils, the belt facies, the carbonate reservoir in the inner and outer ramp was deposited between the ramps. Allochems frequency, supporter texture, tangential Oolite without Micrite, the environment is energetic [25] [27]-[30] and development this process is one of the important characteristics of carbonate shoal and carbonate ramps [31]. Microfacieses of these facies belts are as follow.

\section{1) Peloid Grainstone}

Allochems of this facies are mainly ploid with a very large percentage of small pieces of bivalves, gastropoda, algae and echinoides. Context fractures are filled by ferrous cement and asperity. The context of very small amounts of limy limestone is negligible. The text of facies is asperity and rarely iron cement and texture of greenstone are sometimes diagonal tissue stratification. According to the sorting and rounding seeds, having greenstone texture, lack of calcareous matrix, presence of haploid indicating the energetic environment such as barrier (shoal) [25].

\section{2) Orbitolina bioclast wackestone/packstone}

Allochems of this facies mainly consist of benthic microfossils such as Textularia, Natiloculina, Alveolina and Milolids, drawn and conical Orbitolina with a very large percentage of small pieces of bivalves, gastropods, and algae. Ferrous cement filled fractures context. Allochems are sporadically in parts and in some part joined. The space between Allochems is filled by mud. It is seen the color of light gray limestone facies in field for the average thickness of the layer (samples 11, 28, 29, 34, 42, 57, 95, 110, 118). The presence of Orbitolina drawn and cone-shaped shell with a small microfossils such as shell fragments, this facies indicate a shallow water conditions, light intensity, high light enough food energy and the environment barrier (shoal) [21] [32].

\section{3) Bioclast Bivalvida packstone-Floatstone}

The main allochems of this facies, including benthic foraminifera, a variety of Miliolids, along with fragments of coral, bryozoan, algae (Dacicladacea) components bivalves drawn large an amount of less than $10 \%$ are between allochems microcrystalline seen in 
these facies allochems rarely have stuck together and seeds float on low density and high proportion of text micritic rock covers (samples 108, 98, 19, 13). The distinguishing feature of this sub-facies deposits are increased sorting and cementation. Bivalve's components whose drawn large less than $10 \%$ are large stretches indicator energetic deposition conditions. So barrier microfacies have been formed above the waves effect [33].

\section{4) Bioclast Algae Rudstone}

The main constituent of this allochems for constitute of this facies, including benthic foraminifera, Miliolids types, along with fragments of coral, Miliolids, bryozoan, green algae and large drawn the amount they are above 10 percent, between allochems Hara fills sparit. Frequency of seeds in comparison with micritic context is denser. And seeds for the presence of allochems are often fossilized algae (105 samples).

The presence of the large amount of green algae and pulled them over $10 \%$ in sequence, indicating the formation of deposits in the warm sea and shallow (10 - 50 meters) offshore. Roundness sorting and abundance of grain and sparitic as dominant orthocam and lack of microcrystalline, marker high energy is microfacies. This facies is formed in a high energy represents a barrier [21] [34].

\section{5) Orbitolina bioclast Grainstone}

The main allochems for constituent of this facies, include $\mathrm{S}$ benthic foraminifera as a variety of Miliolids, Textularia, including parts of the Orbitolina, bivalves context fractures filled by cement, mining asparait, corals, bryozoan, green algae, between allochems Hara sparait filled seeds micritic more than text fractures filled by cement asparit hardware (example 47). Allochems that is rounded and elongated, in a cement sparait is one of the properties of energetic barrier canals [35]. In this microfacies presence of dark and thick with clams foraminifera Textularia and Miliolids also environmental conditions such as shallow, abundant food and intensity of light and energetic barrier.

\subsubsection{Lagoon Facies Belts}

\section{1) Bioclast Orbitolina wackestone-packstone}

Allochems the main for constitute of this facies, including benthic foraminifera as Natilocolina, Cristalidina, Orbitolina cone-shaped, Textularia, along with fragments of corals, echinoderms, Miliolids, green algae are seen between allochems microcrystalline. In these facies the seeds aren't alongside with each other and a high proportion of text is micritic stone and low-density grains float. These facies composed of microcrystalline (sample 1, 15, 20, 27, 33, 37, 43, 59, 103, 115). Changes in shell morphology are dependant of depth and conditions of the depositional environment. The genus of Orbitolina like a shell in depth detection and differentiation is important sediment under different environments [36] facies contain Orbitolina the presence of foraminifera shells extracted more flat and the walls were distinguished. These porcelaneous in the environment with relatively high salinity light to penetrate the shallow waters of the lagoon environment are attributed [37]. 


\section{2) Bioclast Algae wackestone-packstone}

Allochems the main constituent of this facies, including echinoderms, Textularia, bivalves, Miliolids, drawn sickle large algae Dasycladaseh (Litocadum) facies are abundant in seeds and grains to form a dense text micritic is variable and sometimes this is taken apart denser facies have been formed (sample 4, 17, 24, 38, 45, 52, 93, 113, 124). The presence of green algae and benthic foraminifera with the mud matrix and bioturbation indicate that the facies are formed in a shallow and low-energy environment light line ray radiation is characteristic of lagoon environment [38]. Microcrystalline being formed according to the facial expression of the faces in a shallow and low-energy waves placed relatively high salinity light line [38].

\section{3) Bioclast mudstone}

Allochems of this facies is very low, which includes parts little tiny algae (Salpingoporerla), bivalves, gastrapoda an important loss. This facies is composed of micrites and treatment of small diamond-that shaped funeral were formed during the process can be observed (sample 18). This facies with uniform texture of fine grained limestone and dark and pure micritic with regard to the formation of the microcrystalline and the facial expression of faces in a relaxed environment and low energy can lagoon [39] [40].

\section{4) Orbitolina Bivalvida packstone}

Allochems the main constituent of this facies include drawn Snail shape Orbitolina, Textularia, Miliolids, echinoderms, bivalves are drawn in large abundance of grain facies of the text are changeable and micritic grains used for dense texts of micrite (sample 22). This fine facies with variable knitted mud to backup seeds to the original Orbitolina micritic or wackstone to Pakstone. Allochem's skeletal parts including ostracods, organic shells and micritic is haploid Miliolids, and field observations of moderate to thick layer of gray limestone. Place of this facies is in shallow waters and low-energy sedimentary microfacies and light this line waves lagoon depositional environment is recommended [40] (Figures 3-5).

\subsection{Depositional Environment}

Based on the type of micro-facies, their vertical changes, the type of skeletal components, depositional environments of the Gadvan and Darian formations in the study area include the shallow waters of the open marine, barrier and lagoon. It is worth mentioning that in the studied samples, the facies related to tidal environment were not observed. Depositional environments are specific ramp with a gentle slope to the beach area with shallow water without fracture. It is noteworthy that lead to specific domains [20] [41] to lack of turbidity facies in the study section, this type of ramp is hemoclical, because it indicates that the limy platform and slope modest increase from shallow to deep environments, such a model but of Khuzestan [42] and the Southern Persian Gulf have been identified [20] Dominant microfauna of Lower Cretaceous formations are Gadvan and Darian Orbitolina. To the size and shape of their lives Orbitolina usually epiphytic fauna is free [43] and Orbitolina internal platform in shallow waters abound with cone-shaped shell [44]. So there are genera and species of Orbitolina with 

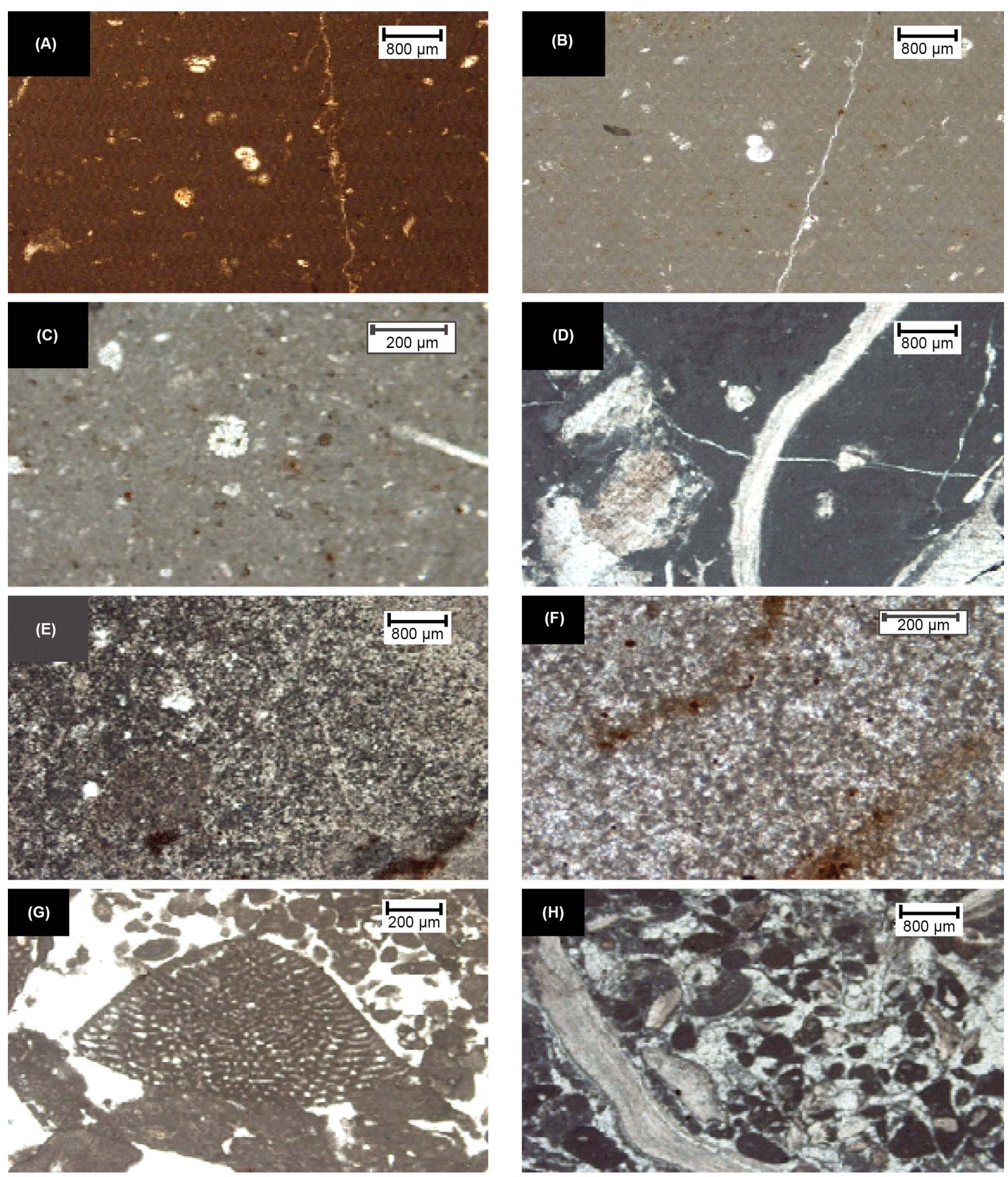

Figure 3. Microfacies of the Gadvan and Darian formations in south Semirom: (A), (B) Microfacies A1, Planktonic Mudstone (sample no. 54), (C) Microfacies, A2 bioclast wackstone (sample no. 10), (D) Microfacies, A3, bivalves wackstone (sample no. 6), (E), (F) Microfacies B1, ploid greenstone (number of sample No. 125), (G), (H) Microfacies B2 Orbitolina bioclast greenstone (samples no. 57). 

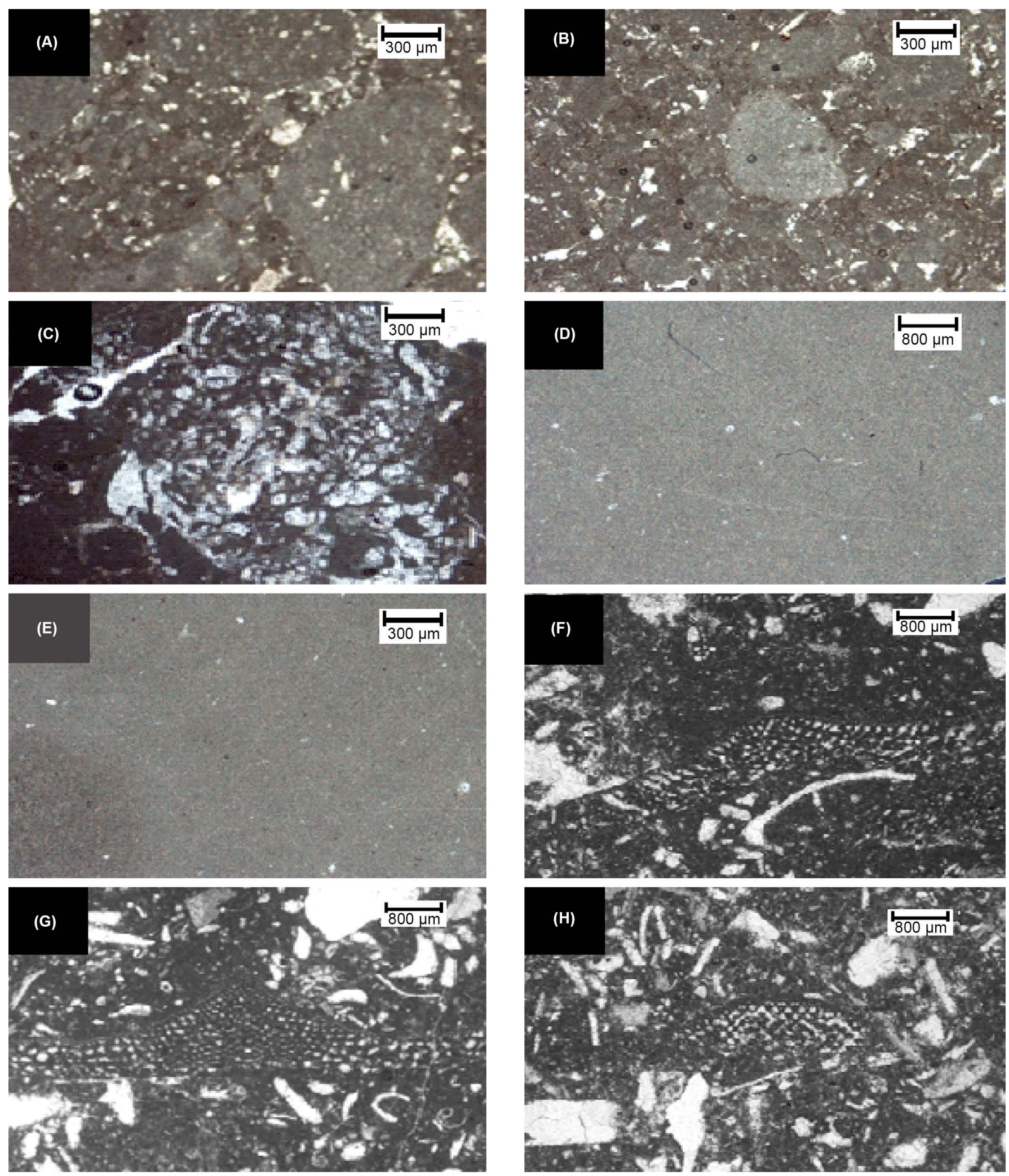

Figure 4. Microfacies of the Gadvan and Darian formations in south Semirom: (A), (B) Microfacies C1 bioclast Orbitolina wackestone-packstone (samples no. 27, 15), (C) Microfacies, C2 bioclast Algae wackestone-packstone (samples no. 17), (D), (E) Microfacies C3, bioclast mudstone (number of samples. 18), (E), (G), (H) Microfacies C4, Orbitolina Bivalvida packstone (samples no. 22). 

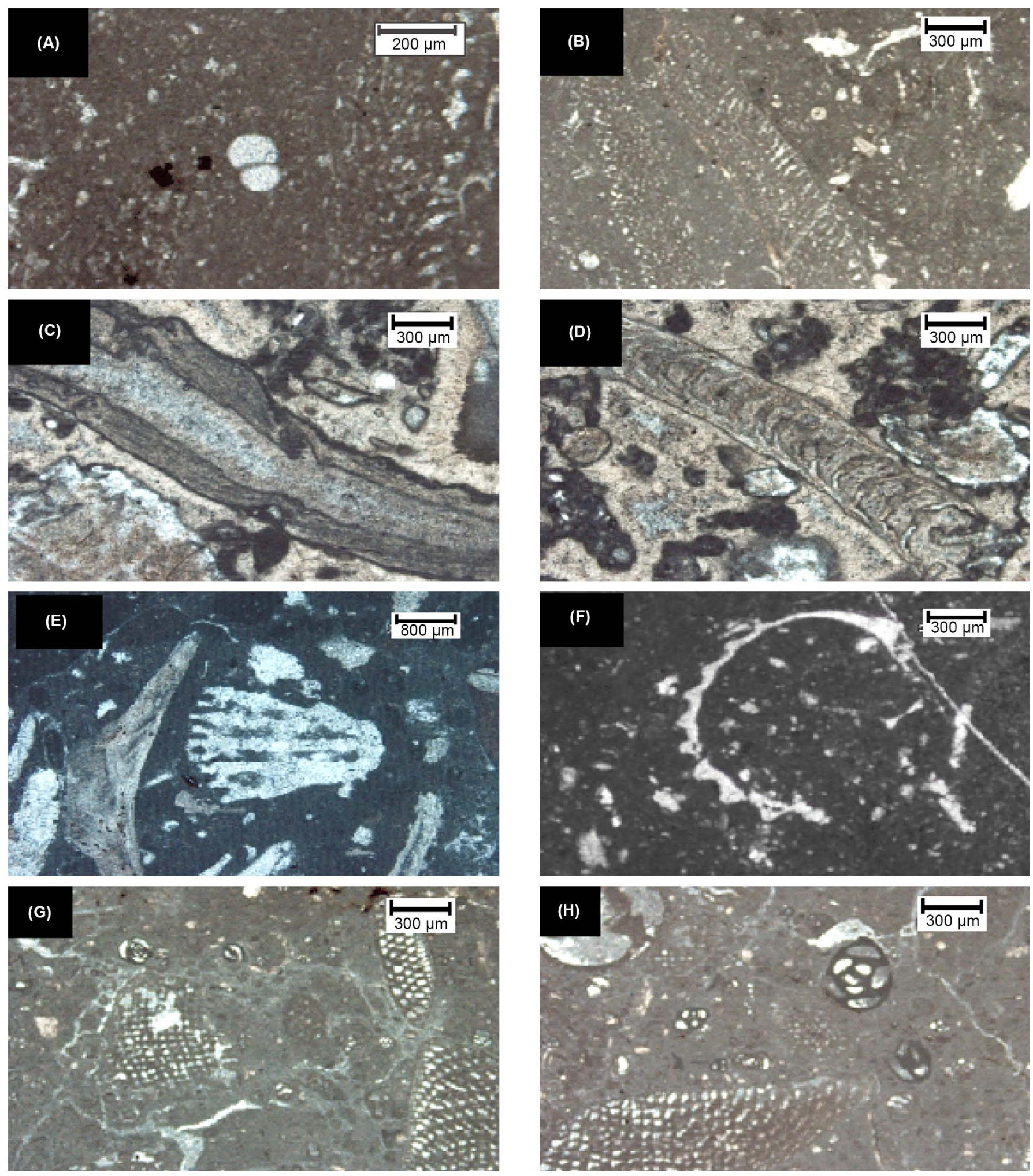

Figure 5. Microfacies of the Gadvan and Darian formations in south Semirom: (A), (B) Microfacies B2 Orbitolina bioclast wackestone-packstone (samples no. 28, 34), (C), (D) Microfacies, B4 bioclast Algae rudstone (sample no. 105), (F), (E) Microfacies B3, bioclast bioclast Bivalvida packstone - Floatstone (number of samples 108,19), (G), (H) Microfacies C1, bioclast, Orbitolina wackestone-packstone (samples no. 33, 59). 
shelly short cone as an indication of sedimentation in the internal platform (Figure 6).

\section{Sequence Stratigraphy}

The sedimentary rocks of a basin are divided into sequences so that the discontinuities, and also they are separate currencies. Studied sedimentary sequences, diagnosis and vertical changes of depositional environments which depend on the relative level changes are determined seas [45]. Sequences are a part of the lowstand system tract (LST), transgressive system tract (TST), highstand systems tract (HST), and the maximum flooding surface (mfs), separated by sequence boundaries type 1 (SB1) and type 2 (SB2) respectively [46] [47]. Vertical changes of facies of Gadvan and Darian formations in the southern part of Semirom identified three sedimentary sequences type 3 with Late Barremian - Aptian age. The lower boundary sequence of Fahliyan Formation in the study area indicates a sequence boundary type 1 (SB1) and boundary between Gadvan and Darian formations is a sequence boundary type 2 as a transitional contact. The upper boundary with Kazhdumi Formation is disconformable (SB1, Figure 7).

\section{1) Sequence 1 (sq1)}

The first sequence with Late Barremian - Early Aptian age has 250 meters thickness. Progressive facies of this sequence are from A2, A3, B2, B3, B5, C1, C2, C3, and C4. The sedimentary system tracts includes a progressive system tract (TST), and highstand systems tract (Ealy and Late HST). The rule of this sedimentary sequence, layers of calcareous fossils A1 was deposited in the lagoons with discontinuous boundary of attrition (SB1) on oolitic limestone of Fahliyan Formation. Barremian sediments have deposited and Barremian calcareous fossils $\mathrm{A} 1$ of the time for sea-level rise progressive system tract (TST) were deposited. Changes left by sea-level rise in this system tract drowning at the maximum flooding surface ( $\mathrm{mfs}$ ), with fine balance reaches $\mathrm{A} 3$ facies. Facies Orbitolina bioclast wakstone - pakstone (B2) on the surface sinks disruption religion are blind. The sediments were deposited in shallow water lagoons and as the old system tract, highstand system tract deposits (Early HST) introduced and more facies B3, C1, C2, C3. At the end of the sequence of sedimentary facies Orbitolina without
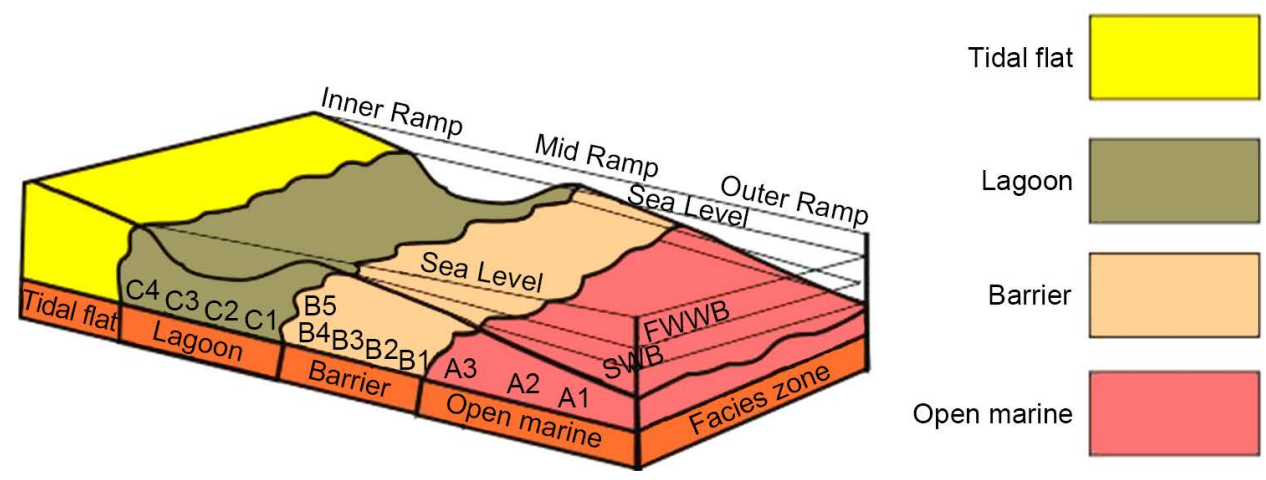

Figure 6. Gadvan and Dariyan significant sedimentary environments in Agh Dagh Mountain in the Zagros Basin, South Semirom; FWWB: The base surface waves, SWB: base of the storm. 


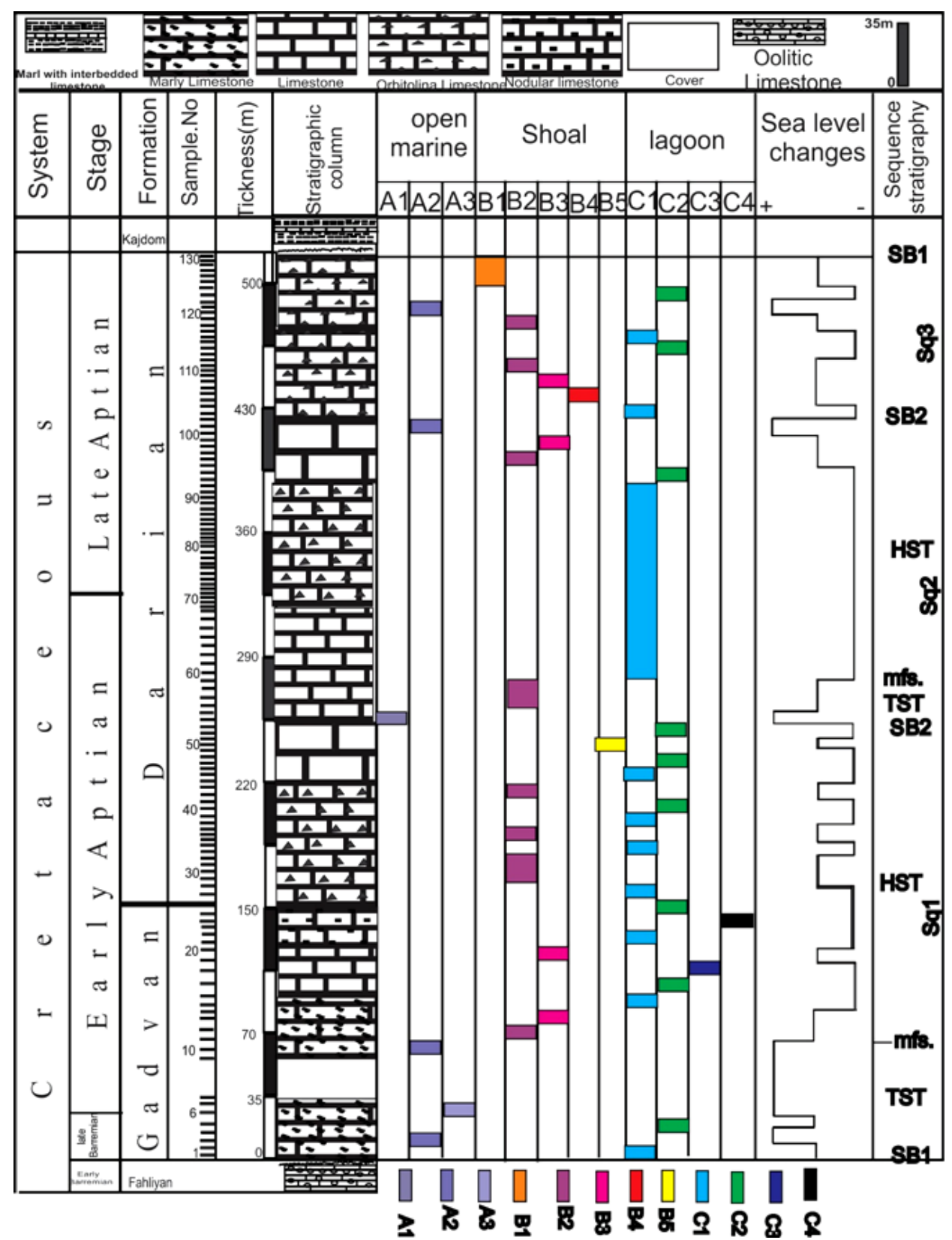

Figure 7. Facies and sequence stratigraphy of Gadvan and Darian vertical distribution in Agh Dagh Mountain in the Zagros Basin, South Semirom.

Bivalves Pakstone (C4), This facies includes Orbitolina drawn shape, Textularia, Miliolids, echinoderms, bivalves left is drawn are large. Late in the system tract, highstand system tract deposits (Late HST) has been introduced. Finally, the second type of sequence boundary (SB2) are included (Figure 7, Figure 8). This succession is the third cycle to No. 3.5 of the water level at the time of Barremian - Aptian global shift of Haq et al. [48] in the form of (Figure 9) is equivalent.

2) Sequence 2 (sq2)

The secondary sedimentary sequences were identified in the upper part of Gadvan 
and Darian formations with thickness of 180 meters. Lower boundary and upper sequence of the second type is SB2. Facies of progressive in the sequence is of A1, B2, C1, and C2. This sequence contains a transgressive system tract (TST) which is depending to former highstand system tract (Early and Late HST). Basal part of the sedimentary sequence, layers of calcareous fossils A1 that have been deposited in the lagoon with Aptian age. The A1 layer of calcareous fossils in lowstand systems tract for the duration of sea-level rise progressively (TST) has been left. Changes in sea-level rise in this system tract drowning at the maximum flooding surface $(\mathrm{mfs})$, with fine facies $\mathrm{C} 2$ comes into equilibrium. Orbitolina facies bioclast wackstone - Pakstone. (B2) on the surface of drowning religion are blind. The sediments were deposited in the shallow waters of the

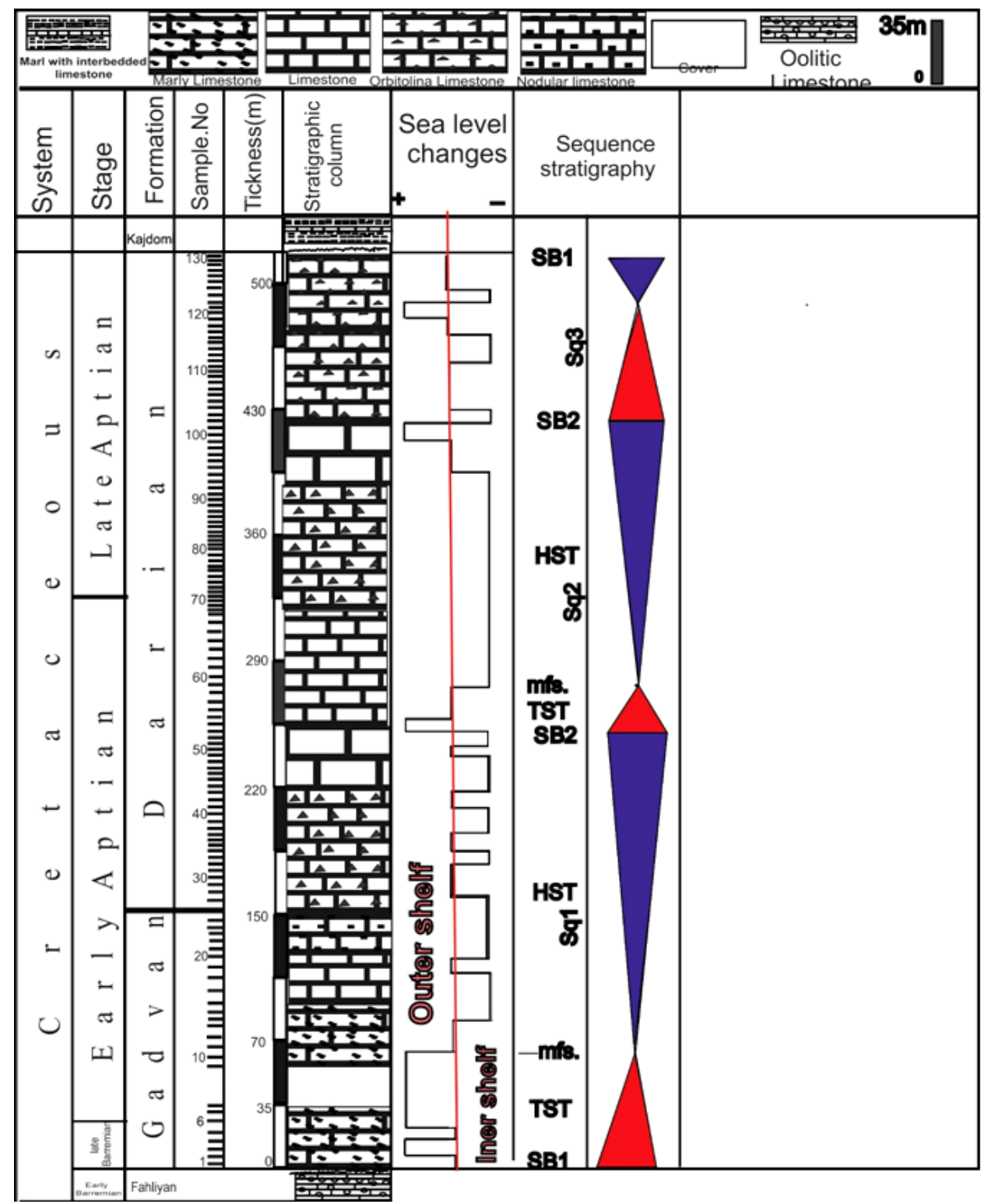

Figure 8. Sequence Stratigraphy of Gadvan and Darian formations in Agh Dagh Mountain, South Semirom. 


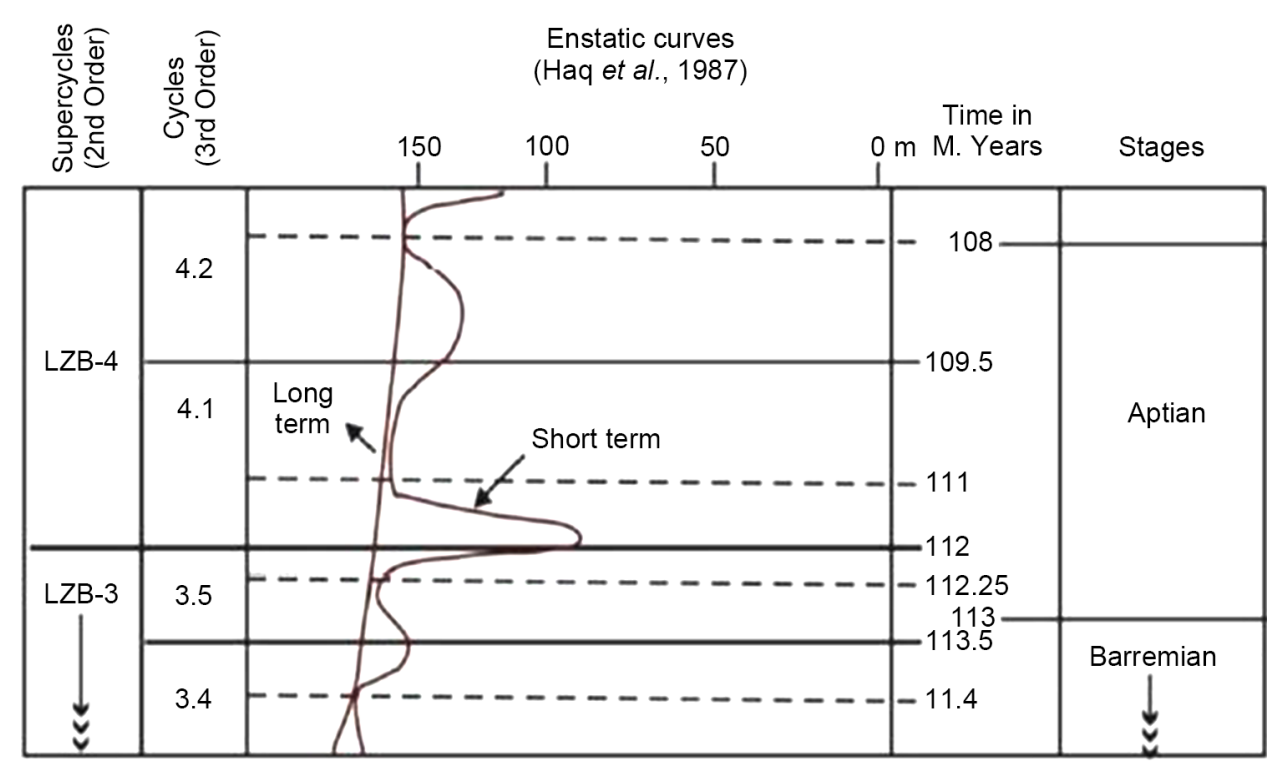

Figure 9. Global sea level changes in Barremian and Aptian period (Haq et al., 1987).

lagoon, and as the old system tract, highstand systems tract deposits (Early HST) have been introduced and then at the end of the sedimentary sequence without bivalves bioclast pakstone - flostone (B3). This facial includes a variety of Miliolids, along with fragments of coral, bryozoan, algae (Dacecladaseh) components whose are less than $10 \%$ of large bivalves are drawn, microcrystalline seen between allochems has been deposited. Late in the package, cumulative deposits (Latest) has been introduced. Finally, the second type of sequence boundary (SB 2 is included (Figure 7, Figure 8). This succession is the third cycle 4.1 Number of global change graph water level in the Aptian of sob Barmian - Aptian Haq, et al. [48] (Figure 9) is equivalent.

\section{3) Sequence 3 (sq3)}

The third sedimentary sequence has been identified in the upper part of Gadvan and Darian formations with thickness of approximately 90 meters. Lower boundary of the sequence is type 2 (SB2) and upper boundary is type $\mathrm{I}(\mathrm{SB} 1)$. Facies of progressive in this sequence is $\mathrm{A} 2, \mathrm{~B} 1, \mathrm{~B} 2, \mathrm{~B} 3, \mathrm{C} 1$, and $\mathrm{C} 2$. transgressive system tract (TST), dependind former highstand system tracts (Early and Late HST). Basal part of the sedimentary sequence, layers of calcareous fossils A2 that have been deposited in the marine environment with Aptian age. A2 limestone layers within the transgresive system tract increase in water level (TST). Changes left by sea-level rise in this system tract drowning at the maximum level ( $\mathrm{mfs}$ ), with fine facies $\mathrm{C} 2$ comes into equilibrium. Ploid grainstone facies (B1) on the surface of drowning religion are blind. The sediments were deposited in shallow water and alokames this facies deliberately ploid with a very large percentage of small fragments of bivalves, gastrapods, algae Thistle ecinoderma an important loss. As a system tract, highstand system tract deposits (HST) have been introduced and at the end of the first sequence boundary (SB1) are included (Figure 7, Figure 8). This succession is the third cycle is equivalent to No. 4.1 of the water level at the time of Barremian - Aptian global shift form [48] (Figure 9). 


\section{Conclusion}

Gadvan and Darian formations in south Semirom composed of 12 microfacies belong to open sea, lagoon and barrier. According to the fine facies distribution and field evidence such as the absence of smears reef and progress of lagoon, these formations were deposited in a carbonate shelf including three internal shelf, intermediate shelf and outer shelf. Also three sedimentary cycles of grade 3 are detected in sequences of Agh Dagh Mountain.

\section{References}

[1] Aghanabati, A. (2004) Considering the Geological Survey and Mineral Explorations. Geological Survey of Iran, Tehran, 586.

[2] James, G.A. and Wynd, J.G. (1965) Stratigraphic Nomenclature of Iranian Oil Consortium Agreement Area: AAPG. $A A P G, 49,2182-2245$.

[3] Wells, A.J. (1965) Lithofacies and Geological History of Khami Group in South West Iran, LOOC Report. No. 1082. (Unpublished Paper)

[4] Kheradpir, A. (1975) Stratigraphy of the Khami Group in Southwest Iran: Iranian Oil Operating Companies, Geological and Exploration Division. Report 1235, 67 p.

[5] Golestaneh, A. (1965) Micropaleontological Study of Khami Group and Jurassic-Cretaceous in Fars Province (Southern Iran). Bulletin de B. R. G. M., Section IV, No. 3, 165-197.

[6] Husinec, A., Velic, I., Fucek, L., Vlalovic, I., Maticec, D., Ostric, N. and Korbar, T. (2000) Mid Cretaceous Orbitolinid (Foraminiferida) Record from Island of Cres and Losinj (Croatia) and It's Regional Stratigraphic Correlation. Cretaceous Research, 21, 155-171. http://dx.doi.org/10.1006/cres.2000.0203

[7] Husinec, A. and Sokac, B. (2006) Early Cretaceous Benthic Associations (Foraminifera and Calcareous Algae) of a Shallow Tropical-Water Platform Environment (M1jet Island, Southern Croatia). Creataceous Research, 20, 1-24.

[8] Habibi, F., Feiznia, S. and Barzegar, F. (1994) Stratigraphy, Sedimentology and Reservoir Evolution of (Upper Dariyan Kazhdumi Tongue, Lower Dariyan and Gadvan Fm.) in Dezful South Area. N. I. O. C., Report. No. 1800. (Unpublished)

[9] Ghalavand, H. (1996) Lithostratigaraphy of Kazhdomi and Dariyan Formations in South and Southwest Regions of Iran (Dezful Embayment and Fars Regions). M. S. Thesis, Shahidbeheshti University, Tehran.

[10] Safari, F., Yazdi Moghadam, M. and Sajjadi, F. (2009) Lower Cretaceous Orbitolinids of Zagros Mountains in Iran and Their Evolutionary Studies. Geophysical Research Abstracts, $11,4659$.

[11] Barzegar, F., Faridi,H., Habibi, F. and Odisho, A. (1986) Stratigraphy, Sedimentology and Riservoir Evolution of Lower Khami Group Dezful South. Report No. 1313.

[12] Amir Shah Karami, M., Shirazi, P. and Mousavi Nia, A.S. (2014) Microfacies and Sequence Stratigraphy Gadvan and Darian between Sivand Area in the North of Shiraz, Zagros Basin.

[13] Motiei, H. (1994) Stratigraphy of Zagros. Geological Survey of Iran, 345-346.

[14] Abyat, A., Baghbani, D., Afghah, M., Kohansal Ghadimvand, N. and Feghi, A. (2012) Microbiostratigraphy and Lithostratigraphy of Fahliyan and Gadvan Formations in Kuh-eSurmeh (Zagros Basin, Southwest Iran). Advances in Environmental Biology, 6, 3078-3086.

[15] Sedaghat, R. (1982) The Sedimentology of the Upper Khami Group Lower Cretaceous, in 
East Khuzestan, SW of Iran. Thesis Submitted for the Degree of PhD, the University of London. (Unpublished)

[16] Afghah, M. and Shaabanpour Haghighi, A. (2014) Aptian Biostratigraphy in South Zagros Basin, Southwest Iran. Geoscience Frontiers, 5, 277-288.

http://dx.doi.org/10.1016/j.gsf.2013.07.001

[17] Wilson, J.L. (1975) Carbonate Facies in Geologic History. Springer-Verlag, New York, 971 p. http://dx.doi.org/10.1007/978-1-4612-6383-8

[18] Dunham, R.J. (1962) Classification of Carbonate Rocks According to Depositional Texture. American Association of Petroleum Geologist Memories, 1, 108-121.

[19] Embry, A.F. and Klovan, E.J. (1971) A Late Devonian Reef Tract on North-Eastern Banks Island, NWT. Canadian Petroleum Geology Bulletin, 19, 730-781.

[20] Burchette, T.P. and Wright, V.P. (1992) Carbonate Ramp Depositional Systems. Sedimentary Geology, 79, 3-57. http://dx.doi.org/10.1016/0037-0738(92)90003-A

[21] Flugel, E. (2010) Microfacies of Carbonate Rocks, Analysis, Interpretation and Application. Springer Verlag, Berlin, $984 \mathrm{p}$.

[22] Dickson, J.A.D. (1965) A Modified Staining Technique for Carbonate in Thin Section. Nature, 205, 587. http://dx.doi.org/10.1038/205587a0

[23] Geel, T. (2000) Recognition of Stratigraphic Sequences in Carbonate Platform and Slope Deposits: Empirical Models Based on Microfacies Analysis of Paleogene Deposits in Southeastern Spain. Palaeogeography, Palaeoclimatology, Palaeoecology, 155, 211-238. http://dx.doi.org/10.1016/S0031-0182(99)00117-0

[24] Bachmann, M. and Hirsch, F. (2006) Lower Cretaceous Carbonate Platform of the Eastern Levant (Galilee and Golan Heights): Stratigraphy and Second-Order Sea Level Change. Cretaceous Research, 27, 487-512. http://dx.doi.org/10.1016/j.cretres.2005.09.003

[25] Adabi, M.H., Salehi, M.A. and Ghabeishavi, A. (2010) Depositional Environment, Sequence Stratigraphy and Geochemistry of Lower Cretaceous Carbonates (Fahliyan Formation), South-West Iran. Journal of Asian Earth Science, 39, 148-160.

http://dx.doi.org/10.1016/j.jseaes.2010.03.011

[26] Romeero, J.E. and Rossel, J. (2002) A Model for the Palaeoenvironmental Distribution of Larger Foraminifera Based on Late Middle Eocene Deposits on the Margin of the South Pyrenean Basin. Palaeogeography, Palaeoclimatology, Palaeoecology, 179, 43-56. http://dx.doi.org/10.1016/S0031-0182(01)00406-0

[27] Tucker, M.E., Calvet, F. and Hunt, D. (1993) Sequence Stratigraphy of Carbonate Ramps: System Tracts, Models and Application to Muschelkalk Carbonate Platform of Eastern Spain. In: Posamentier, H.W., Summerhayes, C.P., Haq, B.U. and Allen, G.P., Eds., Sequence Stratigraphy and Facies Associations, International Association of Sedimentologists Series, Special Publication 18 of the IAS, 397-415.

http://dx.doi.org/10.1002/9781444304015.ch20

[28] Reolid, M., Gaillard, C. and Lathuilière, B. (2007) Microfacies, Microtaphonomic Traits and Foraminiferal Assemblages from Upper Jurassic Oolitic-Coral Limestones: Stratigraphic Fluctuations in a Shallowing-Upward Sequence (French Jura, Middle Oxfordian). Facies, 53, 553-574. http://dx.doi.org/10.1007/s10347-007-0121-5

[29] Palma, R.M., López-Gómez, J. and Piethé, R.D. (2007) Oxfordian Ramp System (La Manga Formation) in the Bardas Blancas Area (Mendoza Province) Neuquén Basin, Argentina: Facies and Depositional Sequences. Sedimentary Geology, 195, 113-134.

http://dx.doi.org/10.1016/j.sedgeo.2006.07.001

[30] Lucia, F.J. (1999) Carbonate Reservoir Characteristics. Springer, New York, 226 p. 
http://dx.doi.org/10.1007/978-3-662-03985-4

[31] Elrick, M. and Read, J.F. (1991) Cyclic Ramp-to-Basin Carbonate Deposits, Lower Mississippian, Wyoming and Montana: A Combined Field and Computer Modeling Study. Journal of Sedimentary Petrology, 61, 1194-1224.

[32] Hohenegger, J. (2005) Estimation of Environmental Paleogradient Values Based on Presence/Absence Data: A Case Study Using Benthic Foraminifera for Paleodepth Estimation. Palaeogeography, Palaeoclimatology, Palaeoecology, 217, 115-130. http://dx.doi.org/10.1016/j.palaeo.2004.11.020

[33] Tucker, M.E. (2003) Sedimentary Rocks in the Field. Department of Geological Sciences, University of Durham, Durham, 252.

[34] Wanas, H.A. (2008) Cenomanian Rocks in the Sinai Peninsula, Northeast Egypt: Facies Analysis and Sequence Stratigraphy. Journal of African Earth Sciences, 52, 125-138. http://dx.doi.org/10.1016/j.jafrearsci.2008.06.004

[35] Wright, V.P. and Burchette, T.P. (1996) Shallow-Water Carbonate Environments. In: Reading, H.G., Eds., Sedimentary Environments. Processes, Facies and Stratigraphy, Blackwell Science, Oxford, 325-394.

[36] Simmons, M.D. and Willams, C.L. (1992) Cretaceous Orbitolinidae (Foraminifera) from Onshore and Offshore South-West England. Journal of Micropalaeontology, 11, 21-30. http://dx.doi.org/10.1144/jm.11.1.21

[37] Reiss, Z. and Hottinger, L. (1984) The Gulf of Aqaba: Ecological Micropaleontology. Springer, Berlin, 354 p. http://dx.doi.org/10.1007/978-3-642-69787-6

[38] Hosseini, S.A., and Conrad, M.A. (2008) Calcareous Algae, Foraminifera and Sequence Stratigraphy of the Fahliyan Formation at Kuhe-Surmeh (Zagros Basin, SW of Iran). Geologia Croatica, 61, 215-237.

[39] Pittet, B., van Buchem, F.S.P., Hillgartner, H., Razin, P., Grotsch, J. and Droste, H. (2002) Ecological Succession, Palaeo Environmental Change, and Depositional Sequences of Barremian-Aptian Shallow-Water Carbonates in Northern Oman. Sedimentology, 49, 555-581. http://dx.doi.org/10.1046/j.1365-3091.2002.00460.x

[40] Sinclair, H.D., Sayer, Z.R. and Tucker, M.E. (1998) Carbonate Sedimentation during Early Foreland Basin Subsidence: The Eocene Succession of the French ALPS. In: Wright, V.P. and Burchette T.P., Eds., Carbonate Ramps, Geological Society, Special Publications, London, Vol. 149, 205-227. http://dx.doi.org/10.1144/GSL.SP.1999.149.01.11

[41] Read, J.F. (1985) Carbonate Platform Facies Models. AAPG Bulletin, 69, 1-21.

[42] Timurid, A., Vaziri Moghadam, H. and Amyrbkhtyar, H. (2004) Microfacies and Depositional Environment of the Sarvak Fornation in the Khuzestan Region. 8th Symposium of Geological Society of Iran, Shahrud, 3-6 September 2004, 76.

[43] Masse, I.P. (1976) Les calcaires urgoniens de Provence (Valanginien-Aptien inferieur). Stratigraphie, Paléontologie, les paléoenvironments et leur evolution. Thesis, Universite Marseillé, Marseillé, 445 p.

[44] Vilas, L., Masse, J.P. and Arias, C. (1995) Orbitolina Episodes in Carbonate Platform Evolution: The Early Aptian Model from SE Spain. Palaeogeography, Palaeoclimatology, Palaeoecology, 119, 35-45. http://dx.doi.org/10.1016/0031-0182(95)00058-5

[45] Lasemi, Y. (2000) Facies Depositional Environment and Depositional Sequence Stratigraphy of Precambrian Rocks of the Upper and Palozoice. Geological Publishing Country, 180 p.

[46] Emery, D. and Myers, K.J. (1996) Sequence Stratigraphy. Blackwell Science, Oxford, 297. http://dx.doi.org/10.1002/9781444313710 
[47] Nicols, G. (1999) Sedimentary and Stratigraphy. Blackwell Science, Oxford, 355 p.

[48] Haq, B.U., Hardenbol, J. and Vail, P.R. (1987) Chronology of Fluctuating Sea Levels since the Triassic. Science, 235, 1156-1167. http://dx.doi.org/10.1126/science.235.4793.1156

Submit or recommend next manuscript to SCIRP and we will provide best service for you:

Accepting pre-submission inquiries through Email, Facebook, LinkedIn, Twitter, etc. A wide selection of journals (inclusive of 9 subjects, more than 200 journals)

Providing 24-hour high-quality service

User-friendly online submission system

Fair and swift peer-review system

Efficient typesetting and proofreading procedure

Display of the result of downloads and visits, as well as the number of cited articles

Maximum dissemination of your research work

Submit your manuscript at: http://papersubmission.scirp.org/

Or contact ojg@scirp.org 